\title{
MOEDA E PODER LEGISLATIVO NO BRASIL: prestação de contas de bancos centrais no presidencialismo de coalizão"
}

\author{
Fabiano Santos
}

\section{Inês Patrício}

\section{Introdução}

Ao longo do período autoritário, várias agências foram criadas para regular o comportamento da economia brasileira. ${ }^{1}$ Obviamente, não só estas agências tiveram origem no poder Executivo, como também em grande parte das iniciativas, a consulta ao poder Legislativo assumiu caráter puramente ritualístico. ${ }^{2}$ A redemocratização trouxe, entre inúmeros desafios a enfrentar, o problema de como controlar o comportamento dos órgãos da

* Trabalho apresentado no XXV Encontro da Anpocs, no Seminário Temático "Controles Democráticos e Responsabilidade Pública", Caxambu, 17 a 20 de outubro de 2001. Os autores agradecem a Cláudio Couto pelos comentários feitos quando da apresentação deste trabalho, cabendo-lhes, contudo, a responsabilidade exclusiva pelos erros eventualmente cometidos. burocracia pública gerados a partir de 1964, órgãos cujos dirigentes se acostumaram a conviver em ambiente de pouca transparência e grande articulação com os grupos econômicos afetados pela regulação. "Anéis burocráticos", na acepção de Fernando Henrique Cardoso, proliferavam na mesma medida em que a economia se desenvolvia e se tornava mais complexa. Assim, é natural imaginar que a democracia brasileira tenha chegado, entre outras coisas, para resgatar as agências do Executivo da antiga regra autoritária, segundo a qual a aquiescência ao regime deveria ser comprada pelo atendimento a interesses privados de grandes grupos econômicos e corporações.

Pode-se dizer que o exemplo mais conspícuo de agência criada durante o regime militar e que, ao longo do tempo, desenvolveu intensa rede de interações "perigosas" com grupos privados é o do Banco Central. Na mídia, assim como em conversas informais, pululam notícias de insi- 
de information, ao mesmo tempo em que é óbvio o recrutamento de dirigentes do BACEN entre ex e futuros membros do setor financeiro privado. Contudo, devido ao impacto das decisões desta agência específica sobre a vida dos brasileiros, o sistema político não poderia deixar de colocar na agenda a questão do controle das ações, muitas vezes discricionárias, de seus dirigentes. É assim que, no que concerne à administração da moeda, dos bancos, dos juros e do câmbio, a política brasileira passa a viver dilemas semelhantes àqueles das democracias dos países plenamente desenvolvidos, dilemas que podem ser sintetizados no conceito de prestação de contas dos bancos centrais.

Se examinarmos a literatura sobre a prestação de contas dos bancos centrais, ${ }^{3}$ constataremos uma preocupação permanente com a construção de indicadores de tais accountability, basicamente, a partir de três variáveis: os objetivos do banco central, o grau de transparência com que suas diretorias tomam decisões e desenvolvem outras atividades, e a responsabilidade final de seus dirigentes. Tal esforço, todavia, ainda que louvável, apresenta dois tipos de problemas: a) não existe neutralidade no conceito de prestação de contas de um banco central, isto é, o tipo de prestação de contas que se julga adequado depende das hipóteses de teoria monetária que se adotam e do que se considera que devam ser as relações entre política monetária e fiscal, ou seja, dos fundamentos econômicos da análise da credibilidade; b) a prestação de contas dos bancos centrais, além da lei e dos estatutos do banco, depende também da capacidade de controle do Legislativo sobre as variáveis-chave da prestação de contas - os objetivos do banco central, a transparência e a responsabilidade final das decisões de política monetária.

No texto que se segue, defendemos que, em cada país, sejam quais forem as concepções dominantes de credibilidade e a lei relativa aos procedimentos de prestação de contas dos bancos centrais, o controle das atividades por parte destes últimos depende da dinâmica das relações entre o Legislativo, o Executivo e o Banco Central. Vale dizer, o estudo do comportamento Legislativo no controle do Banco Central mostra que é possível haver países com o mesmo nível formal de ac- countability dos seus bancos centrais, mas com dinâmicas de prestação de contas muito diferentes, em função de variáveis vinculadas ao sistema político, tais como, por exemplo, a organização interna do congresso e o modo pelo qual o governo busca sustentação no Legislativo.

A partir das objeções feitas à literatura sobre prestação de contas de centrais banco, nosso objetivo, neste trabalho, é o de investigar a lógica que rege a prestação de contas do BACEN no Brasil pelo poder Legislativo, de forma a ilustrar o argumento de acordo com o qual o controle de bancos centrais seria essencialmente função de variáveis ligadas ao funcionamento do sistema político mais amplo. Estaria o Congresso Nacional instrumentalizado para controlar as ações do Banco Central? Que tipo de controle é exercido? Por quê? Teria o presidente da República poder discricionário sobre a política monetária? Quais as razões que teriam levado o congresso, após 1988, a delegar cada vez maior autoridade ao Banco Central para perseguir a meta da estabilidade de preços? Estariam os congressistas contrariando a sua própria "natureza", 4 ao admitir a supremacia monetária sobre a fiscal, após o Plano Real? Ou seria esta delegação uma escolha racional do congresso, diante dos incentivos institucionais do sistema?

Como forma de responder às perguntas acima formuladas, argumentamos que a prestação de contas do Banco Central depende do padrão de relacionamento que se estabelece entre o Legislativo e o Executivo. Em outras palavras, defendemos que a forma pela qual o Legislativo está inserido no sistema político brasileiro, por intermédio do presidencialismo de coalizão, é a chave para o entendimento do padrão de prestação de contas do Banco Central. Mais especificamente, mostramos que o funcionamento do presidencialismo de coalizão torna a ação fiscalizadora do Congresso objeto de negociações no interior da coalizão de partidos formada para apoiar o governo.

O estudo da prestação de contas do Banco Central no Brasil é feito levando-se em conta por um lado, a evolução da estrutura de prestação de contas do BACEN desde sua criação, em 1964, até a implementação do Plano Real, a partir de 1994 e, por outro lado, o processo de prestação de con- 
tas por meio da CPI dos bancos, instalada em 2000, com grande repercussão na imprensa falada e escrita. A estrutura da prestação de contas é o objeto da seção 3 e o processo, da seção 4 . Na seção 2, promovemos análise crítica da literatura recente sobre prestação de contas de bancos centrais e na seção 4 descrevemos o modelo político brasileiro, o presidencialismo de coalizão e seus impactos sobre a ação fiscalizadora do congresso de agências do Executivo. Na seção 5, apresentamos nossa conclusão a respeito dessas questões.

\section{A prestação de contas dos bancos centrais: comentário crítico da literatura recente}

Há três pressupostos teóricos na literatura a respeito de bancos centrais que merecem ser analisados, pois afetam decisivamente a teoria sobre a prestação de contas.

O primeiro refere-se ao comportamento dos agentes e das variáveis econômicas. Ao construir seus modelos com base na teoria quantitativa da moeda, da neutralidade da moeda, e da hipótese de que os agentes agem segundo expectativas racionais, a literatura sobre credibilidade condicionou a prestação de contas a uma única solução institucional para os bancos centrais, que é a independência para buscar a estabilidade de preços. ${ }^{5}$

Em segundo lugar, ao assumir uma diferença de "natureza" entre técnicos e políticos (Rogoff, 1985; Lohman, 1992), a literatura ignora a possibilidade de barganhas entre esses agentes, os políticos preferindo soluções técnicas, movidos por incentivos institucionais, e os técnicos agindo politicamente, cedendo aos políticos, tanto nos objetivos quanto na transparência dos processos, mesmo que às custas de mais inflação (ou menos desinflação), para obterem alguma outra vantagem de poder.

Em terceiro lugar, ao supor que os legislativos agem em relação aos bancos centrais de forma diferente do que em relação às outras agências do Executivo (Lohman, 1998), ${ }^{6}$ ou que aprovam a independência dos bancos centrais para obterem credibilidade internacional (Maxfield, 1997) ${ }^{7}$, ao mesmo tempo em que repudia, sem perceber, a versão distributivista da teoria da inflação, e, portanto, a própria necessidade de bancos independentes, não discute os incentivos institucionais que determinam os diferentes tipos de controle desses bancos centrais pelo Legislativo.

Os bancos centrais modernos descendem de bancos privados que financiaram o Estado e o desenvolvimento econômico, em troca de favores especiais e do monopólio da emissão. Estes bancos foram criados, originariamente, para dar elasticidade ao crédito, adquirindo graus de autonomia diferenciados em vários períodos. É o caso, por exemplo, do Banco da Inglaterra, do Federal Reserve nos Estados Unidos e do Bundesbank na Alemanha. ${ }^{8}$

Foi quando deixaram de ser privados e se tornaram instituições públicas que esses bancos passaram a ser criticados pelo excesso de proximidade em relação aos governos. Esta proximidade, segundo os seus críticos, tornaria a moeda refém de grupos políticos, criando, principalmente nas democracias, ameaças inflacionárias permanentes. ${ }^{9}$

Como solução para os problemas decorrentes da interferência dos políticos na gestão da moeda surgiram duas propostas principais: 1) que se criassem instituições, como bancos centrais independentes, livres de interferências políticas, aos quais fossem dados mandatos diretamente ligados à meta de "estabilidade de preços" e o controle de instrumentos de política monetária; 2) que se estabelecessem metas para a atuação do banco central e determinadas recompensas ou punições de acordo com o cumprimento ou não destas metas.

A independência não significa autonomia para realizar políticas monetárias sem a interferência do governo central; significa, acima de tudo, independência para perseguir a estabilidade de preços, mesmo que isto represente o sacrifício de outros objetivos mais importantes para as autoridades políticas (Cukierman, 1992, p. 370). Ou seja, os bancos centrais são mais independentes se existirem restrições efetivas ao financiamento do setor público pelo Banco Central, quando é objetivo prioritário, definido em lei, a estabilidade de preços. Dado que estes bancos centrais independentes têm a legitimidade assegurada, pela delegação do poder decisório sobre a política monetária por 
parte de legislativos eleitos, não haverá nenhum déficit democrático como conseqüência da independência se os bancos centrais prestarem contas regularmente ao Legislativo. ${ }^{10}$

No final da década de 1980 e início da de 1990, muitos países adotaram legislação relativa à independência do Banco Central. O Tratado de Maastricht, em 1992, exigiu que os membros da Comunidade Européia dessem a independência a seus bancos centrais, como parte dos requerimentos da União Monetária Européia. Apesar de os modelos de credibilidade apontarem a natureza fundamentalmente inflacionária dos políticos, estes aprovaram a autonomia dos bancos centrais em vários países.

Na década de 1990, países como a Nova Zelândia, Canadá, Reino Unido, Finlândia, Suécia, Espanha, Austrália e Brasil aderiram ao regime de metas de inflação. As evidências apontam para uma trajetória descendente de inflação nestes países. Aqueles que não adotaram o regime de metas, por sua vez, como Estados Unidos, Japão, Noruega, Dinamarca, Bélgica, Áustria e Portugal, também apresentaram tendência de queda de inflação na década de 1990 relativamente à década de 1980. Haldane, do Banco Central da Inglaterra e um dos maiores entusiastas do novo regime, afirma que "metas de inflação têm sido propostas durante um período em que as pressões inflacionárias são benignas, em comparação com os anos de 1970-1980. A melhora na performance da inflação nos anos de 1990 que pode ser atribuída à boa sorte [...] permanece uma questão aberta em países com ou sem meta de inflação".

Testes econométricos contribuíram para a crença de que inflação baixa e independência estavam associadas. Estudos empíricos, como os de Alesina e Summers (1993), ao relacionarem o grau de independência dos bancos centrais de catorze países com a média das taxas de inflação do período 1955-1988, registraram um alto grau de correlação entre as variáveis analisadas. ${ }^{11}$

A inclusão das expectativas racionais na teoria monetária, em conjunto com determinadas suposições sobre a forma e o comportamento da curva de oferta agregada da economia, e a hipótese da taxa natural de desemprego (Friedman,
1962) para onde converge o sistema em equilíbrio, levam a concluir que variações esperadas da oferta de moeda não têm efeitos reais na economia. A explicação é a de que os preços se elevariam imediatamente na mesma proporção do aumento da oferta de moeda, ocorrendo somente aumentos nominais de preços e salários na economia.

A maioria dos modelos de credibilidade só considera a versão da escola de expectativas racionais admitindo implicitamente as principais formulações de Friedman quanto à existência de uma taxa natural de desemprego. Entretanto, apesar das duas versões terem fundamentos coincidentes, as conclusões de Friedman quanto à autonomia dos bancos centrais são radicalmente diferentes das dos autores que endossam as teses de credibilidade vinculadas à idéia de expectativas racionais. Além de propor regras fixas como proposta "ótima" para a política monetária, a conclusão de Friedman é que a liberdade é incompatível com a independência de bancos centrais. Assim, afirma: "o dinheiro é demasiado importante para ser entregue a diretores de bancos centrais".

Os keynesianos, por outro lado, crêem na possibilidade e na necessidade de afetar a demanda agregada na economia por algum tipo de intervenção governamental. E não consideram a independência do Banco Central nem eficiente nem democrática, contrapondo-lhe a coordenação das políticas monetária e fiscal pelo Executivo. Para os keynesianos, o pressuposto de haver uma economia monetária em que a moeda não é apenas um meio de troca torna inconsistente a tese de moeda neutra. ${ }^{12} \mathrm{E}$ se a política monetária pode afetar o emprego e a renda, não há razão para os bancos centrais serem isentos de responsabilidade sobre a variável "emprego", ou outras variáveis, como "qualidade de vida" e "estabilidade social". Para um banco central, em vez de apenas um, diversos objetivos, assim como a dependência em relação ao Executivo (sem subordinação necessária da política monetária à fiscal), seriam mais eficientes, e o processo seria mais democrático. ${ }^{13}$ Neste caso, a prestação de contas é mais complicada, pois exige que os bancos justifiquem suas atividades em relação a uma pluralidade de objetivos. 
É possível identificar, a partir daqui, três alternativas de prestação de contas associadas a três diferentes modelos de credibilidade, ou de política monetária:

1. No primeiro padrão, o Banco Central tem apenas um objetivo, que é a estabilidade de preços e só presta contas deste objetivo. O Banco Central não é responsável pela definição da estabilidade de preços em si, como objetivo de política, (este último sendo responsabilidade do governo), mas sim pela produção dessa estabilidade. O "produto" do Banco Central independente é a estabilidade de preços e ele deve ser julgado pela capacidade demonstrada de produzir esse produto. Podemos tomar como exemplo extremo deste caso o modelo do Banco Central Europeu.

2. Uma versão, a que chamaremos "moderada", da credibilidade, assume que há necessidade de um grau elevado de autonomia, para levar a cabo o objetivo da estabilidade de preços, mas não estabelece apenas um objetivo para os bancos centrais, nem os torna completamente independentes dos políticos. Um caso particular deste modelo seria o do Federal Reserve nos Estados Unidos.

3. Uma terceira versão seria a da completa subordinação do Banco Central ao Executivo, e a submissão total da política monetária à política fiscal. A accountability, neste caso, se daria indiretamente, via Executivo, ao Legislativo. É o caso do Banco da Inglaterra durante os anos de 1960 e 1970.

Estas três situações não esgotam, evidentemente, o leque de possibilidades, mas permitem que delas se extraiam outras, intermediárias, entre a completa independência e a completa submissão da política monetária à fiscal, em que a prestação de contas pode assumir diferentes formas, conforme o que se considere ser o objetivo de um banco central.

A literatura sobre prestação de contas dos bancos centrais, ao assumir implicitamente as hipóteses novo-clássicas da credibilidade, sugere que o grau de accountability é tanto maior 1) quanto me- nos objetivos tiverem os bancos centrais - o ideal seria apenas o objetivo estabilidade de preços; 2) quanto mais transparente for a tomada de decisões expressa em relatórios, atas de reuniões e relatórios dos dirigentes aos congressos; e 3) quanto mais bem definida for a responsabilidade dos dirigentes em torno desses objetivos.

De acordo com estes indicadores, o Federal Reserve - que não tem um objetivo único nos seus estatutos, mas dois, a estabilidade de preços e o crescimento sustentado - seria menos accountable, do ponto de vista desta variável, do que o Bundesbank ou o Banco Europeu. E metas de inflação, mesmo quando nada têm a ver com a queda (ou a alta) de preços, informam melhor os agentes econômicos. Relatórios complexos, se numerosos, contam positivamente. ${ }^{14}$

Apesar de o estatuto de muitos bancos estabelecer que seu único objetivo é a estabilização de preços, na prática costuma prevalecer o pragmatismo na condução da política monetária. ${ }^{15}$ Esta literatura não contempla situações de conflito, em que banco e controladores podem não estar de acordo quanto às variáveis da prestação de contas e a forma como estes conflitos são resolvidos. Da mesma maneira que para a independência, a lei não é um bom instrumento para avaliar o grau de accountability de um banco central, uma vez que o resultado final da prestação de contas depende dos pesos dados pelo Legislativo e pelo banco central aos objetivos, à transparência e à responsabilidade final dos dirigentes, os quais, por sua vez, variam de acordo com a análise da credibilidade dos agentes e com as regras que regulam as relações entre estes.

\section{A evolução da estrutura de prestação de contas do Banco Central do Brasil}

A crença de que os políticos, em função das eleições, sempre preferem políticas monetárias expansionistas (Cukierman, 1992), e a hipótese de que abdicam da política monetária, "atando as próprias mãos”, em função da necessidade de credibilidade internacional (Maxfield, 1997), se por um lado introduzem os agentes políticos na teoria 
monetária, não explicam as diferenças no tipo de relações que se estabelecem entre legislativos, executivos e bancos centrais, as quais afetam o resultado da prestação de contas.

Nesta seção apresentamos uma breve recapitulação da história do Banco Central do Brasil desde a sua fundação, em 1964, com o objetivo de identificar os pontos de inflexão em sua estrutura e como o marco normativo de definição da autonomia deste Banco respondeu ao padrão de conflito observado no sistema político, isto é, entre Executivo e Legislativo e no interior deste último, entre os partidos que compõem a base de sustentação do governo. A discussão sobre o processo de prestação de contas do Banco Central dar-se-á de forma mais efetiva dentro da CPI dos Bancos, em 1999, e volta-se para a questão da transparência e das relações entre o sistema financeiro e as diretorias do Banco. Isto será objeto da seção 4.

O Banco Central do Brasil foi criado pela lei n. 4.595 , de 31 de dezembro de 1964, e instalado em $1^{\circ}$ de abril de 1965 , depois de vinte anos de discussão no congresso. Ao longo destes vinte anos vários projetos foram apresentados, alguns tramitaram durante muito tempo e outros nem chegaram a ser considerados. A história da SUMOC, de 1945 até 1964, mostra que sempre houve divergência entre o congresso e a equipe fundadora do Banco Central, que ali se fora concentrando, quanto aos objetivos e à estrutura do futuro Banco e quanto ao papel do Banco do Brasil na política monetária. De 1945 a 1964, o Legislativo consegue efetivamente interferir nos rumos da política monetária, barrando a proposta de criação de um banco central independente. Isto se deve, em parte, à resistência dos deputados e senadores ligados ao Banco do Brasil e, em parte, à resistência dos grupos que dirigem a SUMOC, em criar um banco de corte "populista", preferindo esperar a ocasião adequada para criar um banco central convencional. Quando esta ocasião se apresenta, em 1964, com a ditadura militar, a personalidade conciliadora de Octávio Gouveia de Bulhões determina uma estrutura de banco central menos distante das preferências do congresso do que seria de esperar.

A partir deste momento, podemos, grosso modo, distinguir três fases na história do Banco Central do Brasil, em termos de sua autonomia.
De 1965 a 1967, um período de autonomia moderada, com coordenação de políticas; de 1967 a 1988, quando a autonomia do Banco é eliminada, primeiro de fato, depois de jure ${ }^{16}$ e da Constituição de 1988 em diante, quando se criam de novo condições para uma maior autonomia do Banco, configurando-se a partir de 1994, com o Plano Real, uma supremacia efetiva da política monetária sobre os demais objetivos de política econômica.

A primeira fase, de 1965 a 1967, corresponde à entrada em vigor da Lei 4595 e à instalação formal do Conselho Monetário Nacional, presidido pelo ministro da Fazenda, Octávio Gouveia de Bulhões. A SUMOC ${ }^{17}$ é transformada em autarquia federal, sob a administração de quatro diretores, um dos quais, o presidente, com funções executivas, passando a ser chamada Banco Central da República do Brasil. ${ }^{18} \mathrm{Na}$ origem, a burocracia do Banco Central detém poderes amplos e o mandato do presidente é mais longo do que o do presidente da República. ${ }^{19}$

Esta faceta da história monetária do Brasil mostra a importância relativa do congresso durante o período pré-1964, em que predominava uma coalizão de desenvolvimentistas e representantes das elites agrárias, cuja resultante foi a postergação ou veto a projetos de interesse do Executivo, sobretudo medidas ortodoxas de contenção de gastos. Mostra também que a restrição externa e a opção pelo desenvolvimento substitutivo de importações eram barreiras efetivas ao projeto liberal e, por conseguinte, impunham estratégias de acomodação aos economistas desta corrente, que só se torna efetivamente hegemônica após 1964. A equipe de economistas liderada por Otávio Gouveia de Bulhões, embora preferisse um Banco Central com maior autonomia, deu à instituição, em 1964, forma e atribuições que fossem mais facilmente acomodadas pelos parlamentares. Isto significa que abriu mão de muitas convicções importantes relativas ao que supunha ser melhor para o bom funcionamento da instituição, de modo a incorporar preferências oriundas das correntes majoritárias no congresso. Exemplos dessa estratégia foram a manutenção das prerrogativas monetárias do Banco do Brasil e o fato de se aceitar que o Banco Central tivesse, entre as suas atribuições, o crédito rural. 
$\mathrm{Na}$ fase que se inicia no governo Costa e Silva, em 1967, a independência do Banco Central foi abolida de forma efetiva, primeiro na prática e depois legalmente, devido ao consenso entre os economistas no poder de que ela não era necessária, por razões econômicas e políticas. Este período corresponde não só à perda de autonomia do Banco Central ante o Executivo, como também à perda total do poder do Legislativo na legislação e, por vontade de Costa e Silva e Delfim Netto, a uma mudança na estrutura da tomada de decisões monetárias, que fortalece a Fazenda. O presidente do Banco Central, o autonomista Dênio Nogueira é substituído e em 29 de março de 1967, o Senado aprovou o nome de Ruy Leme, depois de já se terem demitido Dênio Nogueira e toda a diretoria. Pela Lei n. 6.045 de maio de 1974, são revogados os mandatos fixos sob o argumento correto de Mário Henrique Simonsen, de que a revogação de jure apenas reconhecia uma situação de facto.

Esta fase de submissão do Banco Central ao executivo não é interrompida durante os governos Figueiredo e Sarney, apesar da mudança nas relações entre o Banco Central e o Legislativo, este último tornando-se mais ativo na fiscalização dos atos financeiros do governo, ainda no período Figueiredo, devido à abertura política. A dominância do Executivo na definição dos objetivos de política econômica não impede que haja um aumento de intensidade no controle do congresso sobre os procedimentos do Banco Central, e de maior demanda por "transparência". ${ }^{20}$

Foi durante este período que ocorreu o episódio que se tornou um divisor de águas nas relações entre o Tesouro e o Banco Central: a unificação da autoridade monetária com a extinção da conta movimento do Banco Central no Banco do Brasil em 30 de julho de 1986. Com essa medida, disciplinava-se e centralizava-se sob um comando único as decisões relativas à operação de crédito do Banco do Brasil que, por não terem limites em sua maioria, rebatiam negativamente sobre as contas públicas. Além de se retirar do Banco do Brasil, o papel de autoridade monetária, desfazendo-se o sistema misto criado desde a década de 1960, criou-se a secretaria do Tesouro, que tinha como finalidade administrar as contas públicas. Uma série de funções do Banco Central é transfe- rida para o ministério da Fazenda, e a gestão da dívida mobiliária federal é subtraída ao comando do BACEN. Em junho de 1987, o governo cria o SIAFI (Sistema Integrado de Administração Financeira), para o acompanhamento das contas públicas federais. Em novembro de 1987, a emissão de títulos da dívida pública fica condicionada a prévia autorização do congresso Nacional.

Qual o significado de tais decisões de ordem estrutural? Percebe-se que a redemocratização permitiu aos congressistas realocar poder sobre a administração da moeda no país. Ademais, notase que a extinção da conta movimento do Banco Central no Banco do Brasil, pelo Conselho Monetário Nacional, torna clara uma tendência no sentido de transferir efetivamente as funções da autoridade monetária do Banco do Brasil para o Banco Central, desmontando-se o sistema de duplo comando entre as autoridades monetárias. Devemos lembrar que este duplo comando expressava uma acomodação das preferências da coalizão majoritária de congressistas do período pré-1964, formada por interesses da elite rural e desenvolvimentistas. Isto é, a reestruturação das atividades do BACEN em meados da década de 1980, estimulada pelos reclamos de transparência dos legisladores, já denota uma inflexão na postura ideológica hegemônica no interior do congresso.

Vejamos pois o que determinou a Constituição de 1988. Os constituintes decidiram, de um lado, por um aumento da autonomia do Banco Central, e de outro lado, por um maior controle deste pelo Legislativo. Além da revogação da lei 4595/64 e da extinção do Conselho Monetário Nacional, previu-se, na Constituição, um novo arranjo institucional para o Banco Central e para o sistema financeiro, a ser regulamentado posteriormente. $\mathrm{O}$ Banco Central foi proibido constitucionalmente de financiar direta e indiretamente o Tesouro Nacional, pelo artigo 164 da Constituição. Em segundo lugar, foram aprovados dispositivos como o do exercício exclusivo da competência da União para emitir moeda, por meio do Banco Central (art. 21 e 164 inciso I) e o da necessidade de aprovação prévia pelo Senado Federal, em votação secreta, após argüição pública, dos designados pelo presidente da República para os cargos de presidente e diretores do Banco Central (art. 52). Para o Conselho 
Monetário Nacional, pelo artigo 25 do Ato das Disposições Transitórias, previu-se um esvaziamento de suas atribuições.

Na Constituinte, a subcomissão V-C do Sistema Financeiro teve como relator Fernando Gasparian, do PMDB de São Paulo, cujo posicionamento ideológico, nacionalista, discordava da tendência central do plenário, marcado pela corrente denominada Centrão. Duas leis complementares foram previstas, uma no artigo 163 (capítulo II), dispondo sobre finanças públicas, dívida externa e interna, garantias das entidades públicas e fiscalização das instituições financeiras, emissão e resgate de títulos da dívida pública; outra, no artigo 192, (capítulo IV), dispondo sobre as normas que regem o Sistema Financeiro Nacional, e, mais especificamente, sobre a organização, funcionamento e atribuições do Banco Central. O debate suscitado pela regulamentação do artigo 192 foi intenso, dentro e fora do congresso. Além de críticas específicas aos incisos I e II do artigo 192, referindo-se à previsão de separação das instituições bancárias das não bancárias, as maiores críticas, que vieram principalmente do setor financeiro, foram direcionadas ao parágrafo 3, que estabelece uma espécie de lei de usura para os juros reais. Segundo o parágrafo, as taxas de juros reais, incluindo comissões e quaisquer outras remunerações, direta ou indiretamente relacionadas à concessão de crédito, não podem ser superiores a $12 \%$ ao ano.

Um fator a destacar é a convergência da opinião dos técnicos que passaram pelo Banco Central, nos anos de 1980, e o dos políticos que faziam parte do Centrão, para a defesa de um modelo de Banco Central independente, com o único objetivo de manter a estabilidade de preços. Tal convergência é a chave para o entendimento das relações entre BACEN e Legislativo para todo o período posterior ao da Constituinte. A decisão de não regulamentar o artigo 192 é exatamente expressão dessa tensão existente na base de apoio ao governo Sarney, entre nacionalistas à esquerda do espectro ideológico e políticos conservadores, membros do PMDB e PFL, mais simpáticos a um novo modelo de relações entre Estado e economia no país. O conflito na base manifestou-se claramente na dificuldade de aprovação um único texto que tratasse de forma consensual todos os aspectos do sistema fi- nanceiro e, além disso, fosse capaz de regulamentar o parágrafo terceiro. Ao mesmo tempo, a decisão de não regulamentar mostra que o Centrão foi bem-sucedido em sua estratégia de prorrogar medidas consideradas muito à esquerda, mantendo o status quo de delegação ao Executivo e ao Banco Central quanto à definição da política monetária.

A evolução da estrutura de prestação de contas do BACEN demonstra que os políticos, sejam os do Executivo ou do Legislativo, aprofundam esta tendência de delegar prerrogativas de administrar a política monetária ao Banco Central, mas aprimorando os mecanismos de monitoramento das ações de seus dirigentes pelo congresso. Após 1994, a autoridade monetária passa a ser centralizada no Banco Central, aumentando a capacidade do Executivo em determinar os objetivos da política monetária. Medidas de saneamento do sistema financeiro são tomadas também após o Plano Real, aproveitando o amplo apoio parlamentar ao governo do presidente Fernando Henrique Cardoso. ${ }^{21}$ Ao mesmo tempo, a Lei 9.069 de 26 de junho de 1995, que dispõe sobre o Plano Real e o Sistema Monetário Nacional, estabeleceu no artigo 6 do capítulo II, que o presidente do BACEN submeterá ao Conselho Monetário Nacional, trimestralmente, a programação monetária, que deverá ser aprovada pelo Senado Federal, sendo que, com a mesma periodicidade, deverá enviar relatório sobre a execução da programação monetária, além do demonstrativo mensal das emissões de real e das reservas internacionais.

Criam-se, desse modo, critérios para emissão de moeda, controlados pelo Legislativo. Em contrapartida, tanto o Banco Central do Brasil quanto o Conselho Monetário Nacional são beneficiados por ampla delegação de prerrogativas, podendo regulamentar, em curto espaço de tempo, um grande número de transações econômicas, desde a política monetária até o funcionamento de consórcios. ${ }^{22}$

No artigo 8, a lei 9.069 altera a composição do Conselho Monetário Nacional, que passa a ser composto apenas pelas autoridades do Executivo diretamente ligadas à gestão econômica: os ministros da Fazenda, Planejamento e o presidente do Banco Central do Brasil ${ }^{23}$ e, em seguida, é criado o COPOM, pela circular do Banco Central de 20 de junho de 1996, à semelhança do Federal Open 
Market Committee do Banco Central dos Estados Unidos (FOMC) e do Central Bank Council do Banco Central Alemão. Composto pelos oito membros da Diretoria Colegiada do Banco Central do Brasil, com direito a voto, sendo presidido pelo presidente do Banco Central - que tem o voto de qualidade -, seu objetivo seria criar para a decisão sobre taxas de juros, um "ritual técnico transparente, à semelhança do que é feito em toda a parte do mundo". ${ }^{24}$ Isto é, o COPOM passa a ter a responsabilidade de estabelecer os objetivos da política monetária e definir a meta de taxa de juros. A estrutura de prestação de contas está então montada, com ampla delegação de poder para autoridades do Executivo e do Banco Central no sentido de definir a política monetária e instâncias bem definidas para que o Legislativo promova atividades de prestação de contas. A próxima seção discutirá as razões que levaram os legisladores a estruturarem suas relações com o Banco Central dentro desse quadro normativo específico e as conseqüências desse modelo para o processo de prestação de contas.

\section{Legislativo, presidencialismo de coalizão e controle do Banco Central}

Na seção anterior, lembramos que, em vários momentos da história do Banco Central do Brasil, as decisões relativas à sua estrutura normativa foram afetadas por tensões oriundas das correntes em conflito no congresso. É chegado o momento de conhecer as características essenciais do sistema político brasileiro, mais especificamente, as relações entre os poderes Executivo e Legislativo e como estas influem na prestação de contas do Banco Central pelos legisladores.

As características essenciais do sistema político brasileiro são a separação de poderes e o multipartidarismo. Dada a baixíssima probabilidade de que o partido do presidente seja majoritário nas duas casas do congresso, nossa prática institucional tem sido a do presidencialismo de coalizão: o presidente organiza sua base de sustentação por meio da distribuição de postos na estrutura do Executivo e verbas orçamentárias aos grandes partidos, e es- tes garantem os votos necessários à aprovação do programa de governo. Ademais, a Constituição de 1988 dotou o presidente de inúmeros instrumentos de intervenção nos trabalhos legislativos, ao passo que no âmbito interno do Legislativo os líderes partidários tornaram-se capazes de disciplinar o comportamento de seus membros em plenário. Isto é, se o governo está disposto a negociar cargos e verbas em troca de votos no parlamento, e os partidos estão dispostos a trocar votos no parlamento por cargos e verbas, o presidente sabe que tal pacto funcionará de forma aproximada ao estabelecido inicialmente, vale dizer, o montante de cadeiras dos partidos aliados será aproximadamente o montante de votos recebidos em favor das propostas de seu interesse. A este modelo de relacionamento entre governo e parlamento, a literatura tem chamado de presidencialismo de coalizão. ${ }^{25}$

$\mathrm{Na}$ verdade, o presidencialismo de coalizão consiste em um complexo sistema de interações políticas entre membros do Executivo, burocratas, membros do legislativo e líderes partidários. O presidente organiza sua base de apoio nomeando, para os ministérios, políticos indicados pelos líderes dos grandes partidos que, por motivos ideológicos ou estratégicos, aceitam fazer parte da aliança governamental. Isto gera uma série de relações de delegação, algumas delas potencialmente conflitivas. Por exemplo, quando o presidente nomeia determinado político para um ministério, a expectativa é que este promova decisões de acordo com a linha definida pelo presidente. Todavia, seu partido possui objetivos políticos próprios, nem sempre consistentes com o programa perseguido pelo presidente. A questão que se coloca é: a quem o ministro obedecera, ao presidente ou aos interesses de seu partido? Até que ponto o presidente tolera divergências quanto ao comportamento esperado de um ministro em nome da manutenção da base do apoio no Legislativo? Do ponto de vista dos partidos, o problema se apresenta de forma semelhante: se um quadro é nomeado para o ministério, é provável que líderes de seu partido cobrem atitudes que satisfaçam seus interesses eleitorais e ideológicos, certamente, entretanto, este político sofrerá pressões para que a política do presidente seja 
implementada. Estas perguntas são diretamente vividas pelos membros das coalizões presidenciais e podem ser resumidas no dilema de, um lado, existir a necessidade de cooperar para continuar fazendo parte da base de apoio, e de outro, saber que uma coalizão dilui a imagem própria da agremiação vis-à-vis o eleitorado. ${ }^{26}$

Mas a dinâmica do presidencialismo de coalizão revela fontes alternativas de tensão, alternativas mais diretamente ligadas ao tema do controle do Banco Central. Em primeiro lugar, é fundamental lembrar que a política econômica é decisiva para os destinos políticos de um governo. $\mathrm{O}$ sucesso nesta área garante boa vida com a base parlamentar, ao passo que, em momentos de crise, as dissidências e posições de independência adquirem maior legitimidade dentro dos partidos da coalizão. Em segundo lugar, cabe lembrar que, por conta mesmo de seu caráter decisivo, políticas econômicas e monetárias estarão sempre seguindo a orientação do presidente, o que, em alguma medida, gera entre alguns parceiros da coalizão a percepção de estarem alijados das decisões governamentais mais relevantes. A questão torna-se então a de saber como os líderes dos partidos coligados reagem à possibilidade de que as decisões econômicas se afastem excessivamente daquilo que seria aceitável para os demais membros da bancada, grupos de apoio e eleitores.

Argumentamos que o padrão de relacionamento do Legislativo com os órgãos do Executivo expressa as tensões inerentes ao funcionamento do presidencialismo de coalizão. Para que isto fique claro, é preciso considerar, em primeiro lugar, a estrutura de delegação própria a este sistema: em sua origem encontra-se o eleitorado, que delega poderes para dois agentes distintos, o presidente $\mathrm{e}$ o congresso. Em seguida, o presidente delega poderes para ministros e burocratas, tendo em vista promover seu programa de governo. Os congressistas, por sua vez, delegam poderes ao presidente e a seus ministros e, internamente, às lideranças partidárias e às comissões. Segundo Amorim Neto e Tafner, este modelo institucional brasileiro é, na verdade, um complexo de delegações cruzadas, sendo sua complexidade "dada pelos altos custos de transação que o controle dessas delegações exige" (Amorim Neto e Tafner, 2001, p.14).
Amorim Neto e Tafner chamam a atenção para o problema clássico da literatura recente sobre delegação, que é o do controle sobre as ações do agente. Por conta de eventual divergência de interesses entre o mandante e o agente, sempre haverá a possibilidade de que este último tome decisões que maximizem seus interesses, mas que divirjam das preferências do primeiro. Por conta disso, isto é, por conta da possibilidade de incorrer em perdas de agenciamento, o mandante investe recursos em atividades de controle das ações do agente. Os custos de controle são de duas ordens: custos de informação e de coordenação. O primeiro tipo de custo surge porque nem sempre é possível saber se o comportamento do agente é do interesse do mandante. Nestes casos, este incorre em custos de informação na tentativa de tornar transparente seu comportamento e, dado que existe assimetria de informação, sendo o agente mais bem capacitado para escamotear as informações relevantes ao mandante, estes custos podem se tornar insuportáveis, dissipando inteiramente as vantagens da delegação.

Os custos de coordenação surgem quando o principal é um agente coletivo e não individual. Vários problemas daí decorrem: dificuldade para coordenar os esforços dos participantes no sentido de observar o comportamento do agente; incentivos para um comportamento free rider; e dificuldade para o estabelecimento de propósitos comuns aos membros da coletividade relevante. Novamente, os custos para superar os problemas de coordenação em mandantes coletivos podem se tornar proibitivos, diluindo todo e qualquer incentivo para a delegação de tarefas.

Os meios consagrados para superar os custos de informação e coordenação são: procedimentos formais que obriguem os agentes a prestarem contas de suas atividades; seleção de agentes dotados de interesses comuns aos do mandante; acionar grupos e indivíduos com incentivos para observar e influenciar o comportamento dos agentes (o chamado alarme de incêndio). Com estes recursos, o mandante estaria capacitado a controlar o agente, incorrendo em custos pelo menos aceitáveis. Passemos agora à adaptação dessa estrutura de análise para o caso do controle do Banco Central pelo congresso. 
O controle do BACEN é caso paradigmático de um problema de ordem mais geral: o controle da burocracia pública no presidencialismo brasileiro. Segundo a Constituição de 1988, a prerrogativa de se criar órgãos públicos, assim como de emissão de diversos tipos de projetos de lei relativos à administração pública é exclusiva do presidente da República. Isto quer dizer que, de um ponto de vista formal, a burocracia do Estado brasileiro é agente de um único mandante, o presidente, o que serve de contraponto imediato à experiência norte-americana, na qual a decisão de criar e fechar agências é monopólio do congresso. A prerrogativa, contudo, de fiscalizar as ações do Executivo é, no Brasil, tarefa por excelência do Legislativo, sendo assim, é também responsabilidade dos legisladores o controle das decisões dos membros das burocracias do Estado. O interessante a se notar aqui é que o funcionamento do presidencialismo de coalizão torna a ação fiscalizadora do congresso objeto de negociações "no seio das coalizões interpartidárias formadas para sustentar o governo" (Amorim Neto e Tafner, 2001, p. 14).

Tomemos o caso do BACEN, por exemplo. A política monetária é formalmente conduzida pelo presidente do Banco Central e implementada por sua diretoria. A nomeação de seu presidente, bem como de seus diretores, é responsabilidade do presidente da República, evidentemente, após consulta ao ministro da Fazenda e aprovação por maioria do Senado Federal. Obviamente, uma vez nomeados e aprovados presidente e diretores do BACEN, a linha mestra da política monetária passa a ser obra de três atores fundamentais: Nada é feito, em termos de moeda, juros e câmbio, sem que seja acompanhado de perto pelo presidente da República, pelo ministro da Fazenda e pelo presidente do Banco Central. O governo, por sua vez, obtém apoio para suas políticas, notadamente a política econômica, por meio da montagem de coalizão partidária no congresso. Os problemas de agenciamento advindos desta estrutura são: de que maneira os partidos de sustentação do governo podem controlar a orientação do presidente e equipe econômica quando estas se afastam da preferência mediana da coalizão de apoio? De que maneira os congressistas podem evitar coalizões distributivas de burocratas e legisladores que impõem decisões à revelia da tendência do plenário, mas que protegem os chamados vested interests?

Argumentamos que a forma pela qual o Legislativo está inserido no sistema político, por meio do presidencialismo de coalizão, nos dá a chave para o entendimento dessas questões. Tratemos, inicialmente, do controle das decisões do presidente e de sua equipe quando estas se afastam da preferência mediana da base de apoio. Duas questões são relevantes e merecem atenção neste particular: em primeiro lugar, a questão da sobrecarga de demandas e a da complexidade do tema "política monetária". Os legisladores sofrem forte restrição no que concerne à quantidade de tempo disponível para se dedicar às diversas tarefas relevantes ao exercício de seu mandato. Milhares são os temas a serem tratados, assim como os interesses a serem levados em consideração, e o tempo investido para tratar de um compete com o tempo necessário para tratar dos demais. Por isso, estão sempre buscando formas para economizar esforços e recursos, e a delegação é uma solução quase que natural, tendo em vista o corte nos custos de decisão. Evidentemente, quanto mais complexo o tema sob exame, maior o custo de informação e, portanto, mais tempo a ser investido para tratar de forma adequada a matéria. A política monetária é um desses temas complexos - incerteza e risco de impopularidade sempre rondam decisões relativas à moeda, aos juros e ao câmbio. Trata-se, enfim, de tema em torno do qual giram fortes incentivos para a delegação de tarefas a agentes especializados.

Em segundo lugar, a questão da coalizão. Se, por um lado, os legisladores - membros dos partidos que formam a base de sustentação ao governo - possuem incentivos para delegar a política monetária ao governo, por outro, possuem também incentivos para se diferenciarem de decisões consideradas impopulares e conquistarem apoio político por meio da atividade de fiscalização de ações do Banco consideradas nocivas aos interesses da sociedade. Isto ocorre por conta da própria lógica do presidencialismo de coalizão. É verdade que os partidos precisam cooperar em tal sistema e com base nesta cooperação é que são aquinhoados com postos no ministério. Entretanto, estes partidos também competem na arena eleitoral, pois quanto mais for- 
tes eleitoralmente, maiores as chances de se tornarem hegemônicos no governo. Desta forma, o controle das ações do Banco Central pelo Legislativo funciona como uma espécie de rebatimento das tensões do presidencialismo de coalizão.

Tratemos agora da questão de como o Legislativo se organiza para controlar o Banco Central e evitar perdas dessa ação de controle. Dois desafios apresentam-se neste contexto: em primeiro lugar, evitar que a ação de controle seja amortecida pela articulação entre dirigentes do Banco Central e parlamentares. Neste particular, é importante lembrar que as decisões do Banco Central são essenciais para os interesses de vários legisladores. Para que isto fique claro, basta lembrar que os pareceres do BACEN servem de base para a tomada de decisão a respeito das solicitações de operação financeira de Estados e municípios. Burocratas e legisladores, membros da Comissão de Assuntos Econômicos do Senado encontram-se em contexto privilegiado para o estabelecimento de ganhos mútuos da troca. Sendo a CAE a comissão do Senado Federal responsável pelo exame de proposições ligadas ao sistema financeiro, além da produção de pareceres relativos à nomeação de diretores do Banco, é óbvio o potencial para barganhas entre membros do CAE e dirigentes do BACEN. A questão é: de que maneira a prestação de contas pode ser eficiente tendo em vista a possibilidade de a comissão responsável pelo exame de matéria financeira ter interesse em aquiescer com as preferências dos burocratas do Banco Central? A resposta é uma só: transferir a prerrogativa de investigar a agência para instâncias alternativas ao CAE, como, por exemplo, comissões parlamentares de inquérito.

Uma segunda questão importante diz respeito aos limites da própria prestação de contas. O congresso, no presidencialismo de coalizão, é organizado de forma a promover as políticas preferidas pelas lideranças dos grandes partidos participantes da coalizão governamental. Portanto, o controle da burocracia não pode ocorrer para o prejuízo dos membros da base. Mais uma vez, o tênue limite entre tentativas de diferenciação e interesses decorrentes da cooperação com o governo se manifesta nas ações de controle da burocracia. Os legisladores da base se esforçarão para manter a prestação de contas em limites toleráveis de incerteza, ao pas- so em que membros da oposição tentarão aproveitar as oportunidades fornecidas pelos episódios de prestação de contas para ampliar a visibilidade do conflito e explorar as divisões na própria base governista. Dado que o Legislativo funciona de acordo com os interesses de quem tem poder de agenda, é de supor que a estrutura legislativa de controle do BACEN obedecerá a limites estabelecidos pela base, quando esta é capaz de se unir em torno dos incentivos postos à cooperação.

Vimos, na seção anterior, como as tensões no interior do Legislativo afetaram a evolução da estrutura da prestação de contas do Banco Central. Na próxima, exploramos os efeitos do presidencialismo de coalizão sobre o processo prestação de contas, mediante a análise do caso da CPI dos Bancos.

\section{O processo de prestação de contas: a CPI dos bancos de 1999}

A Comissão Parlamentar de Inquérito do Sistema Financeiro, ou CPI dos Bancos, instalada no Senado, em abril de 1999, foi criada, como consta no relatório, publicado em novembro de 1999, com o objetivo de apurar fatos "de conhecimento do Senado Federal, veiculados pela imprensa nacional, envolvendo instituições financeiras, sociedades de crédito, financiamento e investimento, que constituem o Sistema Financeiro Nacional." 27 Três pontos serão analisados neste verdadeiro processo de prestação de contas: a) a forma como foi criada, a partir de fissuras na base aliada do governo, e a composição da CPI; b) a desativação da tentativa de criar uma CPI mista, como queria o PT, e a tentativa de minimização do Relatório Mercadante, pela base aliada do Governo; e, finalmente, c) os outcomes (resultados) do processo.

De um ponto de vista formal, os seguintes fatos motivaram a CPI dos Bancos:

- Apurar a responsabilidade do Banco Central do Brasil na operação de socorro aos bancos Fontecindam e Marka, socorro que lhes permitiu comprar dólares abaixo da cotação do dia, logo após a desvalorização de janeiro de 1999; 
- Apurar a responsabilidade pelo vazamento de informações que propiciaram a diversos bancos lucros exorbitantes, por ocasião da maxidesvalorização do real, em janeiro de 1999;

- Apurar a responsabilidade das instituições financeiras que se colocaram a salvo da desvalorização cambial, obtendo grandes lucros, enquanto seus correntistas e aplicadores amargaram elevados prejuízos;

- Apurar a responsabilidade pela retirada do país, de forma irregular e fraudulenta, de cerca de 400 milhões de dólares, mediante a utilização do Fiex; ${ }^{28}$

- Apurar os exorbitantes lucros obtidos por bancos estrangeiros pela aplicação majoritária de seus recursos na aquisição de títulos públicos, em detrimento da concessão de crédito aos setores produtivos da vida nacional;

- Apurar as razões pelas quais persiste a fragilidade do sistema financeiro nacional após a maciça injeção de recursos por meio do PROER, evidenciada pela liquidação de diversos estabelecimentos bancários.

As reais motivações para a abertura de uma CPI - iniciada por aliados do governo, contra atividades do próprio governo - todavia, foram as disputas entre PMDB e PFL, alem do descontentamento de parte do PMDB com o tratamento dispensado pelo presidente da República, especificamente, com a demora em nomear algumas indicações de cargos do partido, e com o corte no orçamento do ministério dos Transportes, do PMDB. Vale dizer, a CPI revelou tensões na base de sustentação do governo ao mesmo tempo em que foi organizada para não fugir ao controle desta mesma base.

Convocada por um dos líderes da coligação majoritária, Jader Barbalho, Presidente do PMDB, a CPI dos Bancos teve também maioria do governo na sua composição. À exceção de Eduardo Suplicy (PT-SP), Saturnino Braga (PSB-RJ) e José de Alencar (PMDB-MG), ligado ao governador Itamar Franco, os oito restantes senadores da CPI eram dos partidos da coligação de sustentação do governo (PMDB, PFL e PSDB). O senador João Alberto Souza (PMDB-MA), relator, por exemplo, era homem da confiança do senador José Sarney, "aliado" do governo, e o vice-presidente, senador José Roberto Arruda (PSDB-DF), ex-líder do governo no senado, trabalhou para neutralizar a comissão antes desta ser instalada. Ficou na suplência Pedro Simon (PMDB-RS), que poderia ter uma postura mais agressiva na investigação, e Roberto Requião (PMDB-PR), que teve atuação destacada na CPI dos Precatórios, não foi indicado. Em entrevista, este último considerou que o fato de não ter sido indicado prova que não havia interesse em apurar ou responsabilizar efetivamente nenhum diretor do Banco Central ou de banco privado. Outros senadores da oposição confirmaram esta impressão. ${ }^{29}$

A questão central em termos do controle da CPI referiu-se ao destino do requerimento do deputado Aloísio Mercadante (PT-SP) tendo em vista a criação de uma CPI mista. Os partidos governistas contribuíram com 79 nomes para que Mercadante conseguisse criá-la. Entretanto, os líderes do governo desarquivaram nove pedidos de CPI para evitar que a Comissão proposta fosse instalada, sob a alegação de que uma CPI desta natureza poderia afetar a credibilidade externa do país. Obviamente, a manutenção da CPI na esfera do Senado reduziria o risco das investigações escaparem ao controle da base do governo. Sendo mista, além dos onze senadores titulares e dos onze suplentes, haveria mais onze titulares e onze suplentes compondo a Comissão, sabendo-se que na câmara a representação dos partidos de oposição é maior que no Senado, e sua atuação na CPI poderia ser mais incômoda para o governo. Por outro lado, para a abertura de uma CPI no Senado são necessárias 27 assinaturas e sua composição é feita com onze senadores titulares e onze suplentes, os quais podem participar das discussões, mas só podem votar na ausência do titular. Em suma, ao responder uma questão de ordem de Aldo Rebelo (PCdoB-SP), o presidente da câmara, Michel Temer (PMDB-SP), resolveu que antigos requerimentos para a criação de CPI podiam ser desarquivados, ainda que de legislaturas anteriores. O pedido de Mercadante entrou na fila, atrás de outros onze.

A segunda evidência da tentativa de membros do governo controlarem os destinos da CPI consiste no tratamento dado ao relatório de Mercadante. Segundo este, no mercado pronto do dó- 
lar, alguns bancos saíam da posição vendida para a posição comprada, às vésperas da desvalorização do Real. Segundo o deputado, até 11 de janeiro os bancos vinham vendendo mais dólar do que comprando para entrega imediata, mas, no dia 12, esta tendência se inverteu, tendo-se destacado nove bancos nessa inversão: J. P Morgan, Banco de Boston, ING, Garantia, BBM, Pactual, Matrix, Citibank e Real. Mercadante denunciou, de um lado, a possibilidade de vazamento de informações e, de outro, a transferência de recursos ao setor financeiro. ${ }^{30}$ Denunciou também perdas do Tesouro no mercado futuro de câmbio. À véspera da desvalorização, e do dia 12 até ao final do mês, 24 bancos ganharam na $\mathrm{BM} \& \mathrm{~F}^{31} 10,101$ bilhões de reais. A maior parte do ganho saiu do Tesouro Nacional. Mas 49 bancos perderam 3 bilhões de reais. Parte significativa do mercado financeiro não foi informada da desvalorização. ${ }^{32} \mathrm{O}$ grande perdedor na BM\&F foi o Tesouro Nacional, por meio do Banco do Brasil. Este, em nome do Banco Central, vendeu na BM\&F, 7,385 bilhões de reais. Quase 70\% dos contratos era o Banco do Brasil operando na Bolsa, em nome do Banco Central, numa posição vendedora do dólar.

O depoimento de Mercadante foi primeiro alardeado na imprensa como detentor de informações-chave para o desenlace do processo de investigação. Depois, a imprensa desfez, também com grande alarde, a impressão de que o relatório em que ele se baseara pudesse conter informações importantes, acabando por esvaziar-se o conteúdo deste relatório. Para este esvaziamento contribuíram, se observada a sessão que se segue ao depoimento, os líderes do governo e o próprio Jader Barbalho, senador responsável pelo requerimento da CPI. Estes alegaram que Mercadante não trazia nada de novo e ridicularizaram as informações sobre inside information, a propósito da desvalorização, afirmando que o que teria havido era um comportamento de "manada".

O terceiro ponto relevante diz respeito ao resultado final da CPI. Ela foi encerrada após sete meses de investigação, sem provar venda de informações privilegiadas do Banco Central aos bancos Marka e Fontecindam. Apontou irregularidades no PROER, no socorro e venda de bancos. ${ }^{33}$ Quanto à Encol, apontou falsidade ideológica, trá- fico de influência, e falso testemunho, tendo pedido uma auditoria interna no Banco Central para apurar uma possível omissão da diretoria de fiscalização. ${ }^{34}$ Foi ainda pedido o enquadramento civil e criminal do ex-presidente, Francisco Lopes, e de outros dirigentes do Banco Central, além do de Salvatore Cacciola e dos controladores do banco Fontecindam. O relator concluiu que houve responsabilidade de autoridades e executivos na venda irregular de dólares pelo Banco Central às duas instituições. ${ }^{35} \mathrm{Na}$ sessão final da CPI, os senadores do governo e da oposição insistiram na falta de transparência por parte do Banco Central, lamentando a lentidão com que eram repassadas as informações, assim como na responsabilização final dos envolvidos com atos ilícitos. Confessaram também o desconforto com a fiscalização do Banco Central, pela complexidade do tema, e a fragilidade de acesso a informações.

Pode-se dizer que a solução final da CPI foi positiva para o governo e para os membros de sua base aliada no congresso. A CPI introduziu uma série de modificações legais, que visam sobretudo a disciplinar ou a regulamentar as relações do Banco Central com o sistema financeiro. O Executivo manteve a autonomia do Banco Central e da decisão sobre os objetivos da política monetária, em troca de mais procedimentos formais de prestação de contas, como, por exemplo, uma página de apresentação (home-page) de excelente qualidade técnica, mas cujo viés político é definido pela concepção específica de credibilidade do Banco. Enfim, o governo continuou com apoio para definir a política monetária, invariavelmente voltada para a estabilidade da moeda, e os legisladores criaram mais alternativas para promover o fire alarm. ${ }^{36}$

\section{Conclusão}

A teoria econômica parte da hipótese de que os políticos são, por natureza, agentes distributivistas e, por conseguinte, inflacionários. Contudo, vimos também que o congresso brasileiro, por motivos relativos ao funcionamento do presidencialismo de coalizão, não interfere diretamente na política econômica, delegando-a ao Executivo. No 
caso concreto do Banco Central, a independência deste, que existe de fato após o Plano Real, não é contestada, sendo maior por parte do congresso a exigência de transparência e responsabilidade final das decisões. Como conciliar essas duas constatações? O que nossos resultados sugerem é que a prestação de contas não é um processo definido unicamente por intermédio do estatuto legal que rege as atividades do Banco Central; depende também de variáveis institucionais que condicionam as estratégias dos atores políticos, os quais, de alguma forma, têm poder de interferir no processo de prestação de contas.

Nesse sentido, pode-se dizer que o relacionamento do BACEN com o congresso durante o governo Fernando Henrique Cardoso expressa um "equilíbrio", na medida em que o peso que a coalizão governista fornece à variável "objetivos da política monetária" não se afasta sobremaneira do peso dado pelos dirigentes do Banco Central à mesma variável. A tensão incide sobre as variáveis "transparência e responsabilidade final", lugar por excelência das atividades de fire alarm e position taking por parte dos congressistas. Vale dizer, a atividade de controle estrutura-se partidariamente: todos os partidos fiscalizam, sendo que os da oposição fiscalizam mais no intuito de desgastar o governo - lembremos que o deputado Aluísio Mercadante (PT-SP) apresentou à CPI um relatório detalhado sobre as atividades do Banco Central de compra e venda de dólares às vésperas da desvalorização. É irônico que, na estrutura do presidencialismo de coalizão, a oposição cumpra o papel de terceiro agente, ou seja, aquele que é acionado para promover o fire alarm.

Talvez seja interessante especular sobre configurações alternativas do sistema político no que tange à distribuição de força parlamentar dos partidos e à tendência ideológica do chefe do Executivo. Se, por exemplo, um presidente eleito adota um perfil keynesiano de política monetária e é apoiado por coalizão majoritária no congresso, é de se supor que o conflito em torno da prestação de contas seja transferido do âmbito da transparência e responsabilidade final para o âmbito dos objetivos da política. Em contrapartida, se um presidente é eleito com o mesmo perfil, mas é minoritário no congresso, podemos concluir que o conflito incidirá sobre a seleção das diretorias do BACEN - "os agentes". O desafio, nesse contexto, é saber se o congresso desenvolverá expertise e recursos políticos para uma política genuinamente independente do BACEN relativamente ao Executivo.

\section{NOTAS}

1 Exemplos notórios são: Conselho Monetário Nacional (CMN), Conselho de Segurança Nacional (CSN), Conselho Nacional de Abastecimento (CONAB), Conselho Nacional de Comércio Exterior (CONCEX). Para uma lista completa, ver Santos, 1987, pp. 135-136.

2 Para uma análise da criação do Conselho Monetário Nacional (CMN), assim como das várias portaria que se lhe seguiram ver Werneck Vianna, 1987. Para uma análise do padrão de produção legal durante o período autoritário de 1964 a 1985, ver Pessanha, 1997.

3 Bini Smaghi, 1998; Faust e Svensson, 1999.

4 Os modelos de independência do Banco Central partem da hipótese de que os políticos buscam, essencialmente, a reeleição e, por essa razão, estão sempre dispostos a explorar a existência de um trade-off de curto prazo entre desemprego e inflação adotando políticas monetárias expansionistas. Ver a esse respeito Cukierman, 1992.

5 Ver, por exemplo, os textos de Kydland e Prescott, 1977; Alesina e Grilli, 1992; Barro e Gordon, 1983, 1995; Cukierman, 1992; Goodhart, 1990; Cukierman, Webb e Neyapti, 1993, entre outros.

6 Lohman (1998), ao estudar o caso alemão, assegura que na delegação a bancos centrais, as hipóteses dos cientistas políticos norte-americanos sobre o controle das agências do executivo não se verificam: os legislativos, quando se trata do Banco Central, preferem abdicar do controle sobre a agência e "manietar-se", para evitar o problema da inconsistência no tempo da política monetária.

7 Maxfield (1997) afirma que a aprovação da independência dos bancos centrais nos países em desenvolvimento se deve à busca de credibilidade internacional por parte desses países.

8 O Banco da Inglaterra foi fundado em 1694 por um ato do parlamento para emprestar dinheiro ao governo, em troca de privilégios; ver Cairncross, 1988. O Bundesbank descende do Reichsbank, criado em 1875 e que sempre atuou de acordo com as necessidades do comércio e indústria; ver Holtfrerich, 1988. 
9 O Federal Reserve System foi criado em 1913 por um ato do Congresso, que lhe delegou a autoridade monetária com a intenção de torná-lo independente dos interesses financeiros privados, do governo e de interesses partidários; ver Sylla, 1988.

10 A hipótese de uma maioria eleitoral preferir a "coordenação" das políticas monetária e fiscal não é cogitada.

11 Apesar de os inúmeros estudos mostrarem correlação negativa entre vários proxies para bancos centrais independentes e inflação, não há consenso acerca do sentido da causalidade, nem evidência para países em desenvolvimento. Ver Cukierman, 1992; Cukierman, Webb e Neyapti, 1992; Eifffinger e Schaling, 1993; Al-Marhubi e Willet, 1995; Sobre sentido e causalidade, ver Posen, 1993; Goodhart et al., 1994; Sicsú, 1996. Para o caso de países em desenvolvimento, ver Lohman, 1998 e, Rigolon, 1998.

12 Em economias com mercados de títulos bem organizados e que movimentam volumes consideráveis de recursos, a moeda é um ativo que concorre com os demais pela demanda dos agentes. A política monetária deve visar à troca de rendimentos de juros por lucros compensadores para estimular o crescimento econômico.

13 Ver Krugman, 1996; Rymes, 1996 e Schull, 1996.

14 Na Nova Zelândia, o Banco Central encaminha relatórios semestrais e outro anual, protocolados no parlamento, ao ministro das Finanças e este monitora o cumprimento das metas monetárias. O FED reporta semestralmente ao Congresso. No Chile, o BCC reporta-se anualmente ao presidente da república e ao senado. Na Inglaterra, o parlamento faz argüições periódicas aos administradores do Bank of England. A independência operacional deste banco ocorreu em maio de 1997. Antes de isso acontecer, o secretário do tesouro, representando o governo, controlava o estabelecimento dos instrumentos de política monetária. A partir desta data, o banco passou a ter a responsabilidade de estabelecer a taxa de juros básica e a intervir no curto prazo na taxa de câmbio.

15 Em países de bancos centrais autônomos, como, por exemplo, na Alemanha, nem sempre as situações de conflito entre o Banco Central e o governo são resolvidas unilateralmente pelo Banco; muitas vezes a decisão do governo prevalece.

16 Embora o arcabouço legal se mantenha até 1988, o processo de abertura política determinou uma nova postura do congresso ante o Banco Central, que podemos, para facilitar a análise, estabelecer como a fase que vai de 1979, quando toma posse o general Figueiredo, até 1988.
17 A SUMOC - Superintendência da Moeda e Crédito -, autarquia federal idealizada por Octávio Gouveia de Bulhões, foi criada pelo decreto-lei 7293 de 2 de fevereiro de 1945, com o objetivo de constituir um embrião do futuro Banco Central do Brasil.

18 Depois do Decreto-lei n. 278 de 28 de fevereiro de 1967, este assumiu o nome de Banco Central do Brasil.

19 Segundo Bulhões "a independência poderia ser garantida por meio da estabilidade dos diretores". (ver CPDOC, entrevista com Octávio Gouveia de Bulhões, 1989, p. 174).

20 A análise dos discursos arquivados sugere uma "colcha de retalhos" sem padrão definido, em que os deputados e senadores aproveitam a abertura para dar vazão a uma série de demandas represadas. O agravamento da crise econômica após o ajuste à crise do petróleo, a recessão do início dos anos de 1980, o desemprego e a crise da dívida externa que se segue à moratória mexicana em agosto de 1982 aumentam o flanco exposto do governo à crítica do Legislativo. A série de discursos registrados na seção histórico de debates da câmara contém, para o período Figueiredo (1979-1984), inúmeros pedidos de informação sobre remessa de lucros, sigilo, liquidação extrajudicial de instituições financeiras, gastos com despesas sumptuárias, como as do edifício do Banco, e dados sobre endividamento externo. Há poucas contestações ao domínio do executivo em matéria monetária e financeira, mas algumas denúncias de corrupção.

21 Em agosto de 1994, em consonância com o Acordo de Basiléia, o Banco Central editou a Resolução 2.099, estabelecendo limites mínimos de capital para a constituição de um banco, além de limites adicionais que variavam de acordo com o grau de risco dos ativos. Em novembro de 1995, devido ao agravamento da crise bancária, por meio da medida provisória 1.179 foram criados incentivos fiscais para a incorporação de instituições financeiras, permitindo que a instituição incorporadora contabilizasse como perda os créditos de difícil recuperação da instituição adquirida.

22 Ver Jean Paul Cabral da Rocha, 1999.

23 Franco, no discurso de posse, diz que o Banco deixou de ser "uma câmara setorial da moeda" : o CMN era, como se sabe, integrado por todos os ministros da área econômica, vários da área social, todos os presidentes de bancos oficiais, cinco membros da iniciativa privada, um representante dos sindicatos, outro, o presidente da FEBRABAN, os quais, segundo a medida provisória n. 542 de $1^{\circ}$ de julho de 1994 e a medida provisória do Plano Real, eram partes interessadas nas decisões, onde deveria prevale- 
cer apenas o interesse público e o compromisso com a estabilidade da moeda. Uma interpretação alternativa seria que, ao contrário, se concentrou o poder nas mãos de um pequeno grupo.

24 Franco, 1998.

25 O trabalho seminal é de Abranches, 1988. Recentemente, um número cada vez maior de estudos tem se dedicado ao tema, nem sempre chegando às mesmas conclusões. Ver Santos, 1997; Figueiredo e Limongi, 1999; Amorim Neto, 2000; e Pereira 2000.

26 Este argumento encontra-se muito bem exposto em Amorim Neto, 2001.

27 Criada por meio do requerimento n. 127 de 1999 do senado federal, a CPI teve os poderes que estão previstos no artigo 58, parágrafo terceiro da Constituição de 1988 : "as comissões parlamentares de inquérito, que terão poderes de investigação próprios das autoridades judiciais, além de outros previstos nos regimentos das respectivas Casas, serão criadas pela Câmara dos Deputados e pelo Senado Federal, em conjunto ou separadamente, mediante requerimento de um terço dos seus membros, para apuração de um fato determinado e por prazo certo, sendo suas conclusões, se for o caso, encaminhadas ao Ministério Público, para que promova a responsabilidade civil ou criminal dos infratores".

28 A CPI concluiu que a evasão fiscal por meio do sistema bancário e das facilidades concedidas a instituições financeiras é um dos maiores sintomas da fragilidade do setor público diante do setor privado. Dados apresentados por Everardo Maciel da receita federal mostraram que metade das 530 maiores empresas do país, e 42\% dos 66 maiores bancos não pagam imposto de renda. A isenção de taxação das remessas de juros para pagamentos de empréstimos de empresas brasileiras no exterior foi considerada absurda por Everardo Maciel.

29 Requião é também suplente na CAE.

30 O BBM havia vendido nos dias 5, 6, 7, 8, 9, 11. No dia 12 comprou 26,2 milhões de dólares. O ING fez a mesma coisa. Às vésperas da desvalorização, comprou 57, 9 milhões de dólares. Saiu de uma posição vendedora para uma compradora, alterando sua posição em quase 80 milhões de dólares de um dia para o outro. O Morgan comprou 13, 9 milhões de dólares no dia 12.

31 A BM\&F é uma instituição de hedge, de defesa do mercado, seja em dólar, juros seja em commodities.

32 O que Mercadante quer refutar é a tese comum naquele momento de que teria havido um comportamento de "manada", em que todos, prevendo a desvalorização, teriam corrido ao dólar para proteger-se.
33 Foi pedido ao ministério público que investigasse e denunciasse à justiça duas administrações do Banco Central por socorro a bancos: a de Gustavo Loyola e a de Francisco Lopes. Nas informações encaminhadas à CPI pelo Banco Central esconderam-se dados referentes aos saldos a descoberto do PROER. No rodapé da página do documento com letras miúdas, havia uma informação de que foram usados 12,96 bilhões das reservas bancárias depositadas no Banco Central para cobrir rombos do Nacional, do Mercantil, do Econômico e do Bamerindus. Segundo Jader Barbalho, em O Globo, 26 de novembro de 1999, "é uma baita irregularidade do BC, porque liberar recursos com juros fortemente subsidiados do PROER é uma irresponsabilidade. As explicações do diretor de Fiscalização do BC complicaram ainda mais a responsabilidade da diretoria”. Mas João Alberto concordou em retirar do seu parecer acusação de que o Banco Central sonegara informação à CPI, pois Alvarez confirmou o envio de ofício em 15 de junho.

34 Uma das conclusões principais da CPI foi que houve falhas de fiscalização do sistema financeiro por parte do setor público. Isto ficou evidente nos empréstimos do Banco do Brasil à Encol.

35 Em relação aos dirigentes do Banco Central, pediuse ao ministério público que abrisse inquérito para investigar crimes de peculato, falsidade ideológica, tráfico de influência e falso testemunho. Segundo o relatório da CPI, teriam sido forjados os documentos referentes à compra de dólar futuro aos dois bancos, simulando pedido da BM\&F. Os funcionários que já estariam sendo alvo de duas ações de improbidade administrativa na quarta vara da seção judiciária do Distrito Federal são Francisco Lopes, Cláudio Mauch, Demóstenes Madureira de Pinho, Alexandre Pundek, Maria do Socorro Costa Carvalho e Tereza Grossi. Pediu-se ainda o ressarcimento dos prejuízos com as operações, calculado em 2 bilhões de reais. Eduardo Siqueira Campos (PFL-TO), responsável pelo relatório no que se refere a dados protegidos por sigilo, afirmou que não se constatou nenhuma venda de informação por funcionários do Banco Central a pessoas do mercado financeiro.

36 A expressão foi utilizada pela primeira vez por McCubbins e Schwartz (1984) para denotar o tipo de fiscalização de agências do Executivo predominante no Legislativo. Em vez de promover o monitoramento sistemático da burocracia (o chamado police patrol), os congressistas preferem economizar seus esforços de fiscalização e atuar somente quando acionados por grupos de interesse e eleitores. Estes, ao se verem ameaçados por políticas implementadas pelo Executivo, reclamam junto a seus representantes no congresso, por meio de recursos semelhantes ao acionar de um alarme de incêndio. 


\section{BIBLIOGRAFIA}

ABRANCHES, Sérgio Henrique H. de. (1988), "Presidencialismo de coalizão: o dilema institucional brasileiro". Dados, 31 (1): 5-38.

ALESINA, Alberto \& GRILLI, V. (1992), "The European Central Bank: reshaping monetary politics in Europe", in M. Canzonieri, V. Grilli \& P. Masson (eds.), Establishing a Central Bank: issues in Europe and lessons from the U.S. Londres: Cambridge University Press.

ALESINA, Alberto \& SUMMERS, L. (1993), "Central Bank Independence and macroeconomic performance: some comparative evidence". Journal of Money, Credit and Banking, 25: 151-162.

AMORIM NETO, Octavio. (2000), "Gabinetes Presidenciais, Ciclos Eleitorais e Disciplina Legislativa no Brasil: Coalizão". Dados, 43: 479-520.

(2001), "Marcando posição: uma explicação concisa para a competição partidária sob o segundo governo de FHC". Conjuntura Política, 31.

AMORIM NETO, Octavio \& TAFNER, Paulo. (2002), "Governos de coalizão e mecanismos de alarme de incêndio no controle legislativo das medidas provisórias". Dado, 45 (1): 5-38.

AMTEMBRINK, F. (1998), The democratic accountability of central banks. Ph.D. thesis, University of Groningen, Hart Publishers, Londres.

BANAIAN, K., LANEY, L. \& WILLET (1998), "Central Bank Independence: an international comparison", in Toma \& Toma (eds.), Central Bankers, bureaucratic incentives, and monetary policy, Boston, Academic publishers.

BARRO, R. \& GORDON, D. (1983), "A positive theory of monetary police in a natural rate model". Journal of Political Economy, 91, ago.
(1995), "Rules, discretion and reputation in a model of monetary policy", in Persson \& Tabellini (eds.), Fiscal and monetary policy (vol. 1, Credibility), Cambridge, MIT Press.

BEVILACQUA, Luiz \& PATRÍCIO, Inês. (2000), "Confidence, credibility and 'moderation': the democratic accountability of central banks". Trabalho apresentado no Congresso da International Political Science Association (IPSA), Quebec.

BINI SMAGHI, L. (1998), "The democratic accountability of the European Central Bank". Banca Nazionale del Lavoro Quarterly Review, 205: 119-143.

BLINDER, Alan S. (1998), Central banking in theory and practice. Cambridge, MA, MIT Press.

BRIAULT, C.; HALDANE, A. \& KING, M. (1996), "Independence and accountability". Working Paper, 49, Bank of England.

CAIRNCROSS, Alec. (1988), "The Bank of England: relationship with the government, the civil service, and parliament", in G. Toniolo, Central banks' independence in historical perspective, Nova York, Walter de Gruyter.

CAMPOS, Roberto. (1994), A Lanterna na popa: memórias. Rio de Janeiro, Topbooks, 2 vols.

COUTO, Cláudio Gonçalves. (1997), "A agenda constituinte e a difícil governabilidade". Lua Nova Revista de Cultura e Politica, 39.

CPDOC - Centro de Documentação de História Contemporânea Brasileira. (1989), Entrevista com Dênio Nogueira. .(1989), Entrevista com Octávio Gouveia de Bulhões.

(1990), Entrevista com Casimiro Ribeiro. (1997), Entrevista com Ernane Galveas.

CUKIERMAN, Alex. (1992), Central Bank strategy, credibility and independence: theory and evidence. Cambridge, MA, MIT Press. 
CUKIERMAN, Alex; WEBB, Steven \& NEYAPIT, Bilin. (1992), "Measuring the independence of central banks and its effects on policy outcomes". The World Bank Economic Review, 6: 353-398.

DE HAAN, J. (1997), "The European Central Bank: independence, accountability and strategy". Public Choice, 93: 395-426.

EIJFFINGER, S. C. W. \& SCHALING, E. (1993), "Central Bank independence in twelve industrial countries". Banca Nazionale del Lavoro Quarterly Review, 184: 1-41.

FAUST, J. \& SVENSSON, L. (1999), The equilibrium degree of transparency and control in monetary policy. Working paper 7152, National Bureau of Economic Research, jun.

FIGUEIREDO, Argelina Cheibub \& LIMONGI, Fernando. (1999), Executivo e legislativo na nova ordem constitucional. Rio de Janeiro, Editora FGV.

FIGUEIREDO, Lucas. (2000), Morcegos negros. São Paulo, Record.

FISHER, Stanley. (1977), "Long-term contracts, rational expectations and the optimal money supply rule". Journal of Political ECOnomy, 85 (1): 191-205.

FISCHER, S. (1994), "The costs and benefits of disinflation", in J. O. de Beaufort Wijnholds; S. C. W. Eijffinger \& L. H. Hoogduin (eds.), A framework for monetary stability, Dordrecht/Boston/Londres, Kluwer Academic Publishers.

FRANCO, Gustavo. (1988), "Depoimento à comissão de assuntos econômicos do senado federal", 17 jun.

FRIEDMAN, Milton. (1962), "Should there be an independent monetary authority?", in L. Yeager (ed.), In search of a monetary constitution, Cambridge, Harvard University Press.

(1968), "The role of monetary policy". American Economic Review, pp 1-17, mar.
GOODHART, C.; CUKIERMAN, A. \& SELGIN, George A. (1994), "The banking system and monetary control". Economic Journal, 104, nov.

GORMLEY, L. \& DE HAAN, J. (1996), "The democratic deficit of the European Central Bank". European Law Review, vol. 21, pp. 95-112

GREENSPAN, A. (1993), Statement before the Committee on Banking, Finance, and urban affairs. U. S. House of Representatives, 13 out.

GUIMARÃES, César \& WERNECK VIANNA, Maria Lúcia Teixeira (1987), "Planejamento e centralização decisória: o Conselho Monetário Nacional e o Conselho de Desenvolvimento Econômico", in Olavo Brasil de Lima Jr e Sérgio Henrique Abranches (coord.), As origens da crise: Estado autoritário e planejamento no Brasil. São Paulo, Vértice, Editora Revista dos Tribunais.

HOLTFRERICH, Carl-Ludwig. (1988), "Relations between monetary authorities and governmental Institutions: the case of Germany from the $19^{\text {th }}$ century to the present", in G. Toniolo, Central Banks' independence in historical perspective, Nova York, Walter de Gruyter.

KRUGMAN, Paul. (1999), The return of depression economics. Nova York, W.W. Norton \& Company.

(1996), "Stables prices and fast growth: just say no". The Economist, 3 ago.

KYDLAND, Finn \& PRESCOTT, Edward. (1977), "Rules rather than discretion: the inconsistency of optimal plans". Journal of POlitical Economy, 85: 473-491.

LOHMANN, Susan. (1998), "Federalism and Central Bank independence the politics of German Monetary policy, 1957-1992". World Politics, 50: 401-446.

(1992), "The optimal commitment in monetary policy: credibility versus flexibility". American Economic Review, 82, mar. 
MAXFIELD, Sylvia. (1997), Gatekeepers of growth the international political economy of Central Banking in developing countries. New Jersey, Princeton University Press.

McCUBBINS, Mathew \& SCHWARTZ, Thomas. (1984), "Congressional oversight overlooked: police patrols versus fire alarms". American Journal of Political Science, 28: 165-179.

MENDONÇA, Helder F. (1996), A independência dos bancos centrais: uma análise do debate. Dissertação de mestrado, UFF, dez.

(1998), "Aspectos teóricos e empíricos sobre bancos centrais independentes: uma aplicação para o caso brasileiro". Revista de Economia Aplicada, jan./mar.

PEREIRA, Carlos. (2000), What are the conditions for the presidential success in legislative arena? The Brazilian Electoral connection. Ph.D. dissertation, Graduate Faculty of Political Science of the New School University.

PERSSON, R. \& TABELLINI, G. (1993), "Designing institutions for monetary stability", Carnegie-Rochester Conference Series on Public Policy, 39: 53-84.

PESSANHA, Charles. (1997), Relaçôes entre os poderes executivo e legislativo no Brasil: 19461994. Tese de doutorado, São Paulo, USP.

POSEN, Adam. (1993), "Why Central Bank Independence does not cause low inflation: there is no institutional fix for politics", in R. O'Brien (ed.), Finance and the international economy. Oxford, Oxford University Press.

RIGOLON, Francisco José Zagari. (1993), Independência do Banco Central: o caso do Brasil. Dissertação de mestrado, Rio de Janeiro, Departamento de Economia da PUC, set.

RIGOLON, Francisco J. Z. \& GIAMBIAGGI, Fábio. (1988), "A atuação do Banco Central em uma economia estabilizada: é desejável adotar metas inflacionárias no Brasil?" Ensaios BNDES, 7.
ROCHA, Jean Paul C. Veiga da. (1999), Lei, regulamento e separação de poderes: a capacidade normativa de conjuntura das autoridades monetárias. Trabalho de conclusão de curso do Programa de Formação de Quadros Profissionais do Cebrap, São Paulo.

ROGOFF, K. (1985), "The optimal degree of commitment to an intermediate monetary target". Quarterly Journal of Economics, 110: 1169-1190.

RYMES, Thomas K. (1996), "Autonomous and accountable". Journal of Post Keynesian Economics, 18 (2): 177-187.

SANTOS, Fabiano. (1997), "Patronagem e poder de agenda na política brasileira". Dados, 40: 465-492.

SANTOS, Wanderley Guilherme dos. (1987). Crise e castigo: partidos e generais na política brasileira. Rio de Janeiro, Vértice/Iuperj.

SCHULL, B. (1996), "Federal reserve independence: what kind and how much? Journal of Post-Keynesian Economics, 18 (2).

SEMINÁRIO Reforma do sistema Financeiro Nacional. (1992), Painel coordenado por Mário Henrique Simonsen, São Paulo, Fundação Getúlio Vargas.

SICSÚ, João. (1996), "A tese da independência do Banco Central e a estabilidade de preços: uma aplicação do método cukierman à história do FED". Texto para discussão, IEI/UFRJ, 363.

SOLA, Lourdes; GARMAN, C \& MARQUES, M. (1998), "Banco Central governo democrático". Revista de Economia Politica, 18 (2).

STIGLITZ, Joseph. (1998), "Central banking in a democratic society". The Economist, 146: 199-226.

SYLLA, Richard. (1988), "The autonomy of monetary authorities: the case of the U. S. Federal Reserve system", in G. Toniolo (ed.), Central Banks' independence in bistorical Perspective, New York, Walter de Gruyter. 
TONIOLO, Gianni (ed.) (1988), Central Banks' independence in historical perspective. Nova York, Walter de Gruyter.

VIANNA, Maria Lúcia Werneck. (1987), A administração do milagre: o conselho monetário nacional, 1964-1974. Petrópolis, Vozes.

WALSH, C. E. (1995), "Optimal contracts for central bankers". American Economic Review, 85: 150-167.

WHITEHEAD, Laurence. (2000), "The delicate balance between financial credibility and political accountability: restructuring monetary authority in new democracies". Trabalho apresentado no $18^{\text {th }}$ World Congress of the International Political Science Association, Quebec. 
MOEDA E PODER LEGISLATIVO NO BRASIL: PRESTAÇÃO DE CONTAS DE BANCOS CENTRAIS NO PRESIDENCIALISMO DE COALIZÃO

Fabiano Santos e Inês Patrício

\section{Palavras-chave}

Comportamento legislativo; Bancos centrais; Relações executivo-legislativo; Presidencialismo de coalizão; Comissão Parlamentar de Inquérito

$\mathrm{O}$ artigo analisa as relações entre $\mathrm{O}$ Congresso Nacional e o Banco Central do Brasil através do conceito "presidencialismo de coalizão". Este é utilizado para descrever de forma mais geral o modo pelo qual opera o sistema político brasileiro. Após uma avaliação crítica da literatura contemporânea sobre prestação de contas de bancos centrais, segue-se uma discussão a respeito da evolução da estrutura do Banco Central do Brasil, com ênfase na legislação produzida para regular suas atividades. Finalmente, discute-se a Comissão Parlamentar de Inquérito que investigou o sistema financeiro, mostrando como os conflitos e as decisões da CPI expressaram a lógica de relacionamento entre os partidos governistas e o presidente em nosso modelo político presidencialista e multipartidário.
MONETARY CURRENCY AND LEGISLATIVE POWER IN BRAZIL: CONTROL OF CENTRAL BANKS IN COALITIONAL PRESIDENTIALISM

Fabiano Santos e Inês Patrício

\section{Keywords}

Legislative Behavior, Central Banks, Executive-Legislative Relations, Coalitional Presidentialism, Parliamentary Committee of Inquiry

This article analyzes the relationship between the national congress and the central bank of Brazil through the concept of coalitional presidentialism. The concept is used as a mean to describe the more general functioning of the Brazilian political system. After a critical assessment of the literature on accountability of central banks, attention is given to the evolution of the Brazilian central bank's structure, with special concern to the legal output aiming at the regulation of its activities. Finally, the discussing on the Comissão Parlamentar de Inquérito, created in order to investigate the country's financial system, shows that the conflicts and the outcomes of the CPI could be explained by the logic of interaction between governing parties in the parliament and the president in the context of our political model which combines a presidential system of government and multipartism.
MONNAIE ET POUVOIR LÉGISLATIF AU BRÉSIL: LA PRESTATION DE COMPTES DE BANQUES CENTRALES AU PRÉSIDENTIALISME DE COALITION

\author{
Fabiano Santos e Inês Patrício
}

Mots-clés
Comportement Législatif; Banques
Centrales; Relations Exécutif-Législa-
tif; Présidentialisme de Coalition;
Commission Parlementaire d'Enquête.

L'article analyse les rapports entre le Congrès National et la Banque Centrale du Brésil à partir du concept de "présidentialisme de coalition". Ce dernier est employé pour décrire de manière générale le fonctionnement du système politique brésilien. Après une évaluation critique de la littérature contemporaine sur la prestation de comptes de banques centrales, nous développons une discussion à propos de l'évolution de la structure de la Banque Centrale du Brésil, en mettant l'accent sur la législation produite pour réglementer ses activités. Finalement, nous abordons la question de la Commission Parlementaire d'Enquê-te qui a enquêté sur le système financier, indiquant de quelle façon les conflits et les décisions de cette Commission ont démontré la logique des relations entre les partis du gouvernement et le président dans notre modèle politique présidentialiste et pluraliste. 